\title{
PRIMJENA THOMSONOVOG PRELJEVA U MJERENJU PROTOKA U KANALIZACIJI
}

\section{Igor Dundović}

HIDROING d.o.o,Osijek, dipl.ing.građ.

\section{Lidija Tadić}

Sveučilište J. J. Strossmayera u Osijeku, Građevinski fakultet, prof.dr.sc.

Sažetak: Rad prikazuje osnovne zakonitosti strujanja preko Thomsonovog preljeva koji se često koristi upravo za hidraulička mjerenja protoka. Osim teorijskih postavki, u radu će se prikazati rezultati provedenih mjerenja protoka u kanalizaciji jednog dijela grada Valpova radi kalibracije protoka matematičkog modela kanalizacijskog sustava.

Ključne riječi: mjerenje, protok, kanalizacijski sustav, Thomsonov preljev, kalibracija

\section{APPLICATION OF THOMSON'S OVERFLOW ON THE SEWER FLOW MEASUREMENTS}

\begin{abstract}
This paper presents basic principles of flow over the V-notch weir that is often used specifically for hydraulic discharge measurements. Besides the theoretical part, paper will show results of applying V-notch weir in discharge measurments in sewage system of one part of the Valpovo in order to provide data for discharge calibration of sewage mathematical model.
\end{abstract}

Key words: measurement, discharge, sewage system, V-notch weir, calibration 


\section{Uvod}

Trokutni oštrobridni preljev (poznat i kao preljev s V usjekom) je vrsta preljevne građevine koja svojim oblikom omogućuje izračun protoka unutar otvorenog kanala ili gravitacijskog cjevovoda pomoću samo jednog ulaznog podatka, a to je visina prelijevanja $\left(H_{p}\right)$. Ovakav tip preljeva ima prednosti pred ostalim preljevima, jer zbog svojeg oblika omogućuje preciznija mjerenja kod manjih protoka [1]. Na slici 1 prikazan je trokutni preljev u cijevi gdje su označene osnovne geometrijske veličine: $B=$ ukupna širina preljeva koji je kombinacija Thomsonovog i Bazinovog preljeva $(m) ; H_{p}=$ visina prelijevanja ili preljevna visina $(m) ; b_{p}=$ širina preljevnog mlaza $(m)$ i $\theta=$ kut između bočnih stranica preljeva (kut usjeka).

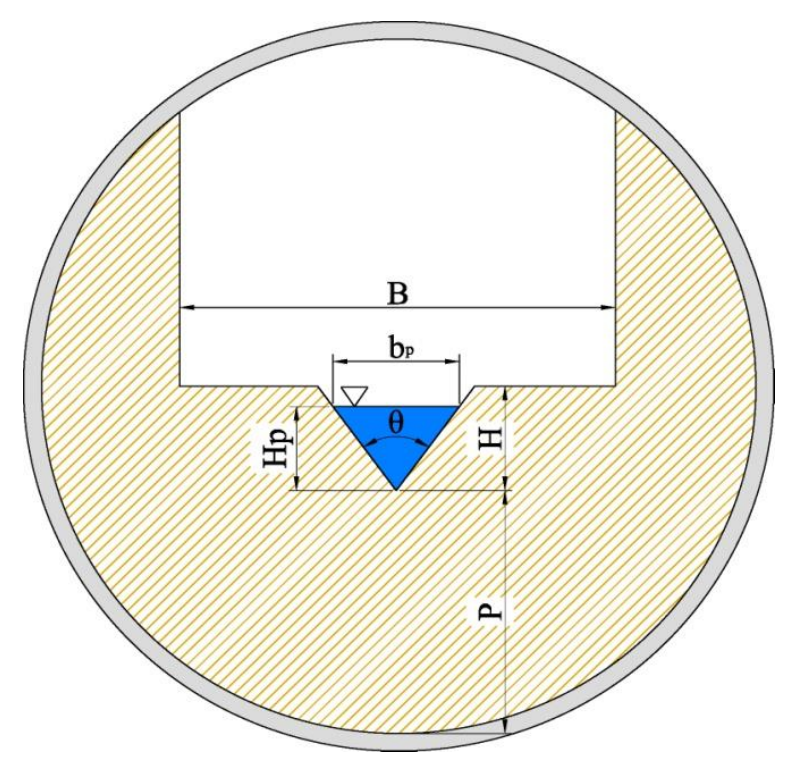

Slika 1 - Trokutni oštrobridni preljev - presjek

Izračun protoka preko trokutnog preljeva omogućava se samo mjerenjem visine preljevnog mlaza, ali je pritom važno poznavati geometrijske karakteristike preljeva, kao i ograničenja primjene koji zajedno određuju točnost rezultata. U tablici 1 prikazani su bitni parametri za dvije skupine trokutnih preljeva, onih s kutom između bočnih strana preljeva $25^{\circ}<\theta<100^{\circ}$, i onih s kutom $\theta=90^{\circ}$.

\section{Tablica 1 - Uvjeti izračuna protoka preko trokutnog preljeva [3]}

\begin{tabular}{|l|} 
Za kut usjeka: \\
$25^{\circ}<\theta<100^{\circ}$ \\
\hline$H p / P \leq 0,4$ \\
\hline$H p / B \leq 0,2$ \\
\hline $0,05 \mathrm{~m}<H p<0,38 \mathrm{~m}$ \\
\hline $\mathrm{P} \geq 0,45 \mathrm{~m}$ \\
\hline $\mathrm{B} \geq 0,9 \mathrm{~m}$ \\
\hline
\end{tabular}

\begin{tabular}{l} 
Za kut usjeka: \\
$\theta=90^{\circ}$ \\
\hline $\mathrm{Hp} / \mathrm{P} \leq 1,2$ \\
\hline $\mathrm{Hp} / \mathrm{B} \leq 0,4$ \\
\hline $0,05 \mathrm{~m}<\mathrm{Hp}<0,6 \mathrm{~m}$ \\
\hline $\mathrm{P} \geq 0,1 \mathrm{~m}$ \\
\hline $\mathrm{B} \geq 0,6 \mathrm{~m}$ \\
\hline
\end{tabular}

gdje su:

- $\quad P=$ visina praga do početka usjeka preljeva $(L)$

- $\quad B=$ ukupna širina preljeva $(L)$

- $\quad H p=$ visina prelijevanja $(L)$ 
Za praktičnu primjenu najprikladniji su preljevi s kutom $\theta=90^{\circ}$, jer jednostavniji geometrijski oblik preljeva utječe na pojednostavljenje općeg izraza za izračun protoka (Giles, 1976) u nepotopljenim uvjetima na preljevu koji onda glasi (1):

$$
Q=1,4 x H p^{5 / 2}
$$

gdje su:

- $Q=$ protok preko preljeva $\left(\mathrm{m}^{3} / \mathrm{s}\right)$

- $m=$ koeficijent protoka preko preljeva

$-\mathrm{Hp}=$ visina prelijevanja $(\mathrm{m})$

Ograničenja primjene:

$-\theta=90^{\circ}$

- $0,05 \mathrm{~m}<\mathrm{Hp}<0,25 \mathrm{~m}$

Izraz (1) naziva se Thomsonova jednadžba, a preljevna građevina koja zadovoljava ograničenja primjene za spomenutu jednadžbu naziva se Thomsonov preljev.

Za slučaj izračuna protoka pomoću mjerenja preljevne visine na trokutnom preljevu kod kojega je kut usjeka $25^{\circ}<\theta<100^{\circ}$, primjenjuje se izraz (2), odnosno Kindsvaterova forumula [3]:

$$
Q=\frac{8}{15} \times \mu \times m \times \sqrt{2 g} \times\left(H p+K_{h}\right)^{\frac{5}{2}} \times \tan \frac{\theta}{2}
$$

gdje su:

- $Q=$ protok preko preljeva $\left(\mathrm{m}^{3} / \mathrm{s}\right)$

- $m=$ koeficijent protoka

- $\quad H p=$ visina prelijevanja $(m)$

- $\mu$ = faktor protoka za $\mathrm{Hp} / \mathrm{P} \leq 0,4 ; \mathrm{P} / \mathrm{B} \leq 0,2$

$-K_{h}=$ korekcijski faktor preljevne visine $(m)$

$-\theta=$ kut usjeka

Faktor protoka $\mu$ i korekcijski faktor $\mathrm{K}_{\mathrm{h}}$ mogu korelirati (slika 2 i slika 3) [3]:

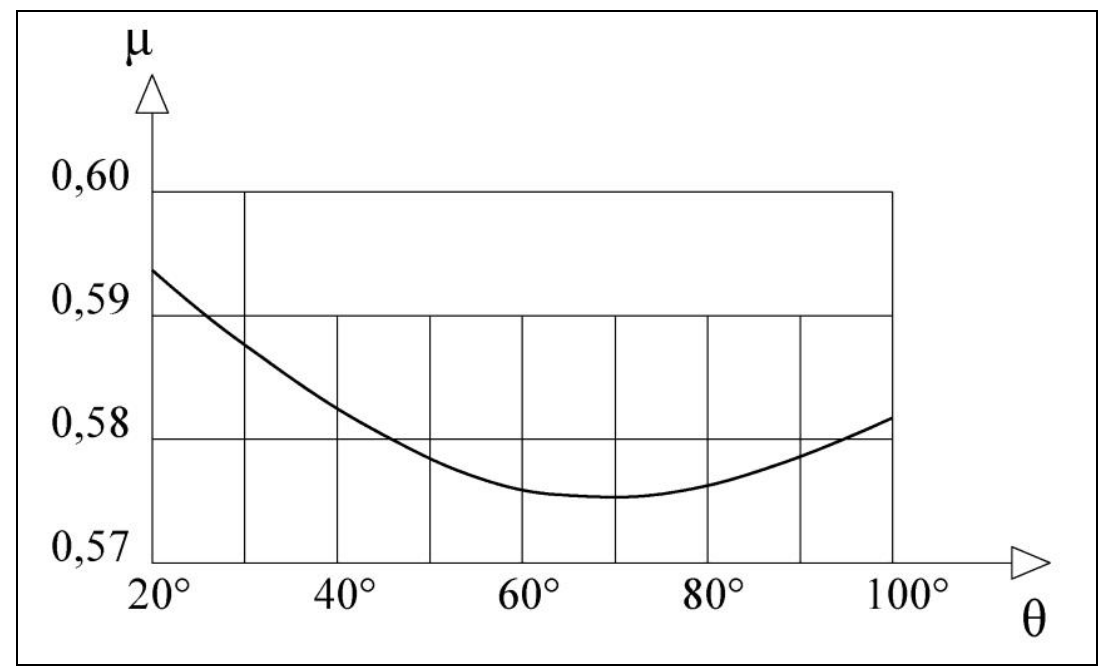

Slika 2 - Faktor protoka $\mu=f(\theta)$ 


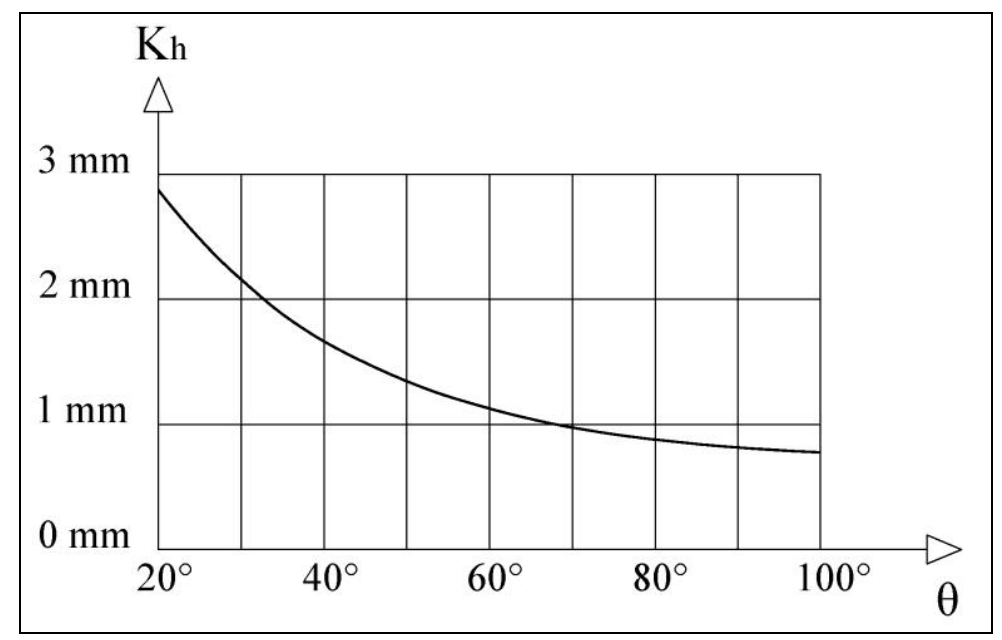

Slika 3 - Korekcijski faktor $K_{h}=f(\theta)$ u [mm]

Ako faktor $\mu$ želimo očitati kao funkciju vrijednosti $\mathrm{Hp} / \mathrm{P}, \mathrm{P} / \mathrm{B}$ i kuta $\theta$, ako je $\theta=90^{\circ}$, možemo koristiti sljedeći graf (slika 4) [3]:

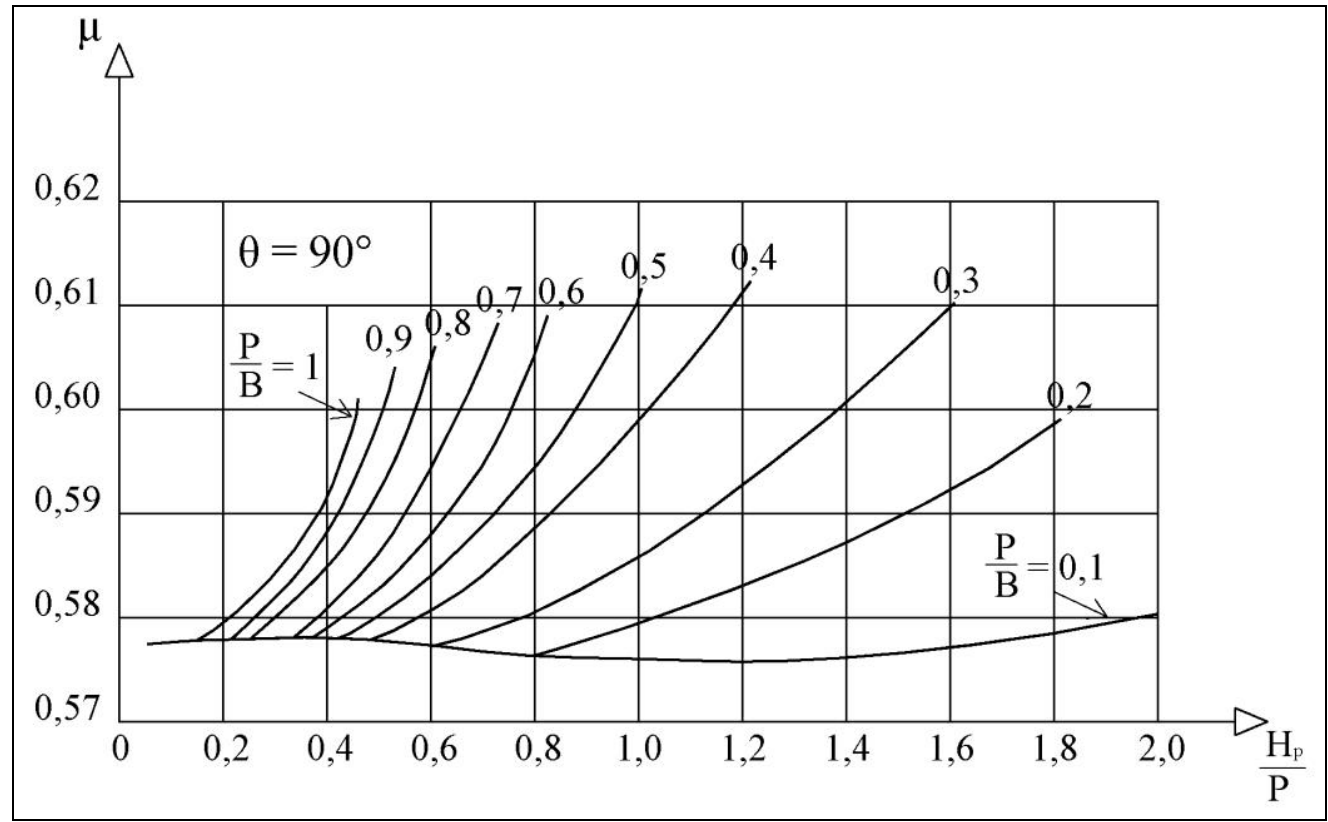

Slika 4 - Faktor protoka $\mu=f\left(H p / P, P / B, \theta=90^{\circ}\right)$

U nastavku se navode još neke jednadžbe koje se primjenjuju kod trokutnih preljeva.

Izrazi (3), (4) i (5) za izračun protoka prema alternativnoj formuli s korištenjem Hendricksovog izraza za faktor protoka $\mu$ [3]:

$$
\begin{aligned}
& Q=\frac{8}{15} \times \mu \times m \times H p^{\frac{5}{2}} \times \sqrt{2 g} \times \tan \frac{\theta}{2} \\
& \mu=\left(0,5775+0,214 \times H p^{-1,25}\right) \times\left(1+\frac{H p^{2}}{b_{p}^{2} \times(H p+P)^{2}}\right)
\end{aligned}
$$




$$
b_{p}=2 \times H p \times \tan \frac{\theta}{2}
$$

gdje su: $b_{p}=$ širina preljevnog mlaza $(m), a P=$ visina ustave do početka usjeka $(m)$.

U svim izrazima pojavljuje se i koeficijent protoka, $m$. To je bezdimenzijska veličina koja ovisi o uzvodnoj visini vode, protoku, visini prelijevanja i tipu preljeva (trokutni, pravokutni, trapezni, kružni itd). Izraz (6) po kojem se računa koeficijent protoka glasi [3]:

$$
m=\left(\frac{H u}{H p}\right)^{u}
$$

gdje su:

- $H_{u}=$ uzvodna visina vode $(m)$

- $H_{p}=$ visina prelijevanja $(m)$

- $u=$ eksponent ovisan o tipu preljevne građevine $(u=2,5$ za trokutni preljev)

\section{Primjer primjene Thomsonovog preljeva}

Primjer primjene Thomsonovog preljeva u ovome radu rezultat je mjerenja protoka u kanalizacijskim cijevima grada Valpova, kao i njihove obrade i analize.

\subsection{Određivanje mjernih lokacija}

Prije samog postupka mjerenja potrebno je odrediti lokacije mjernih točaka na kojima će mjerenja dati najjasniju sliku stanja sustava javne odvodnje nekog područja. Definiranje zona mjerenja počinje s upoznavanjem svih elemenata promatranog sustava kao što su: crpne stanice, preljevi, dimenzije i oblik cijevi, kritične točke sustava, lokacija revizijskih okana, smjer dotoka, geodetske visine, stanje sedimenta, lokacija plavljenja, itd. Za područje grada Valpova definirano je 7 karakterističnih zona s 11 mjernih lokacija na kojima je postavljeno 13 mjernih uređaja. Mjerne zone, prikazane na slici 5, nazvane su prema stranama svijeta na kojima se nalaze tako da imamo sljedeće zone:

- N - sjeverna zona

- NE - sjeveroistočna zona

- E - istočna zona

- W - zapadna zona

- NW - sjeverozapadna zona

- S - južna zona

- SE - jugoistočna zona (rezultati mjerenja u ovoj zoni prikazani su u ovom radu).

U ovome radu prikazani su rezultati mjerenja samo u jugoistočnoj zoni (SE) na lokaciji $A$, pri čemu je korišten pijezometrijski uređaj za mjerenje visine vodnog stupca iznad uređaja i preljev nizvodno od uređaja koji se postavlja unutar cijevi između dvije zone, na slici 5. označen „LW“. 


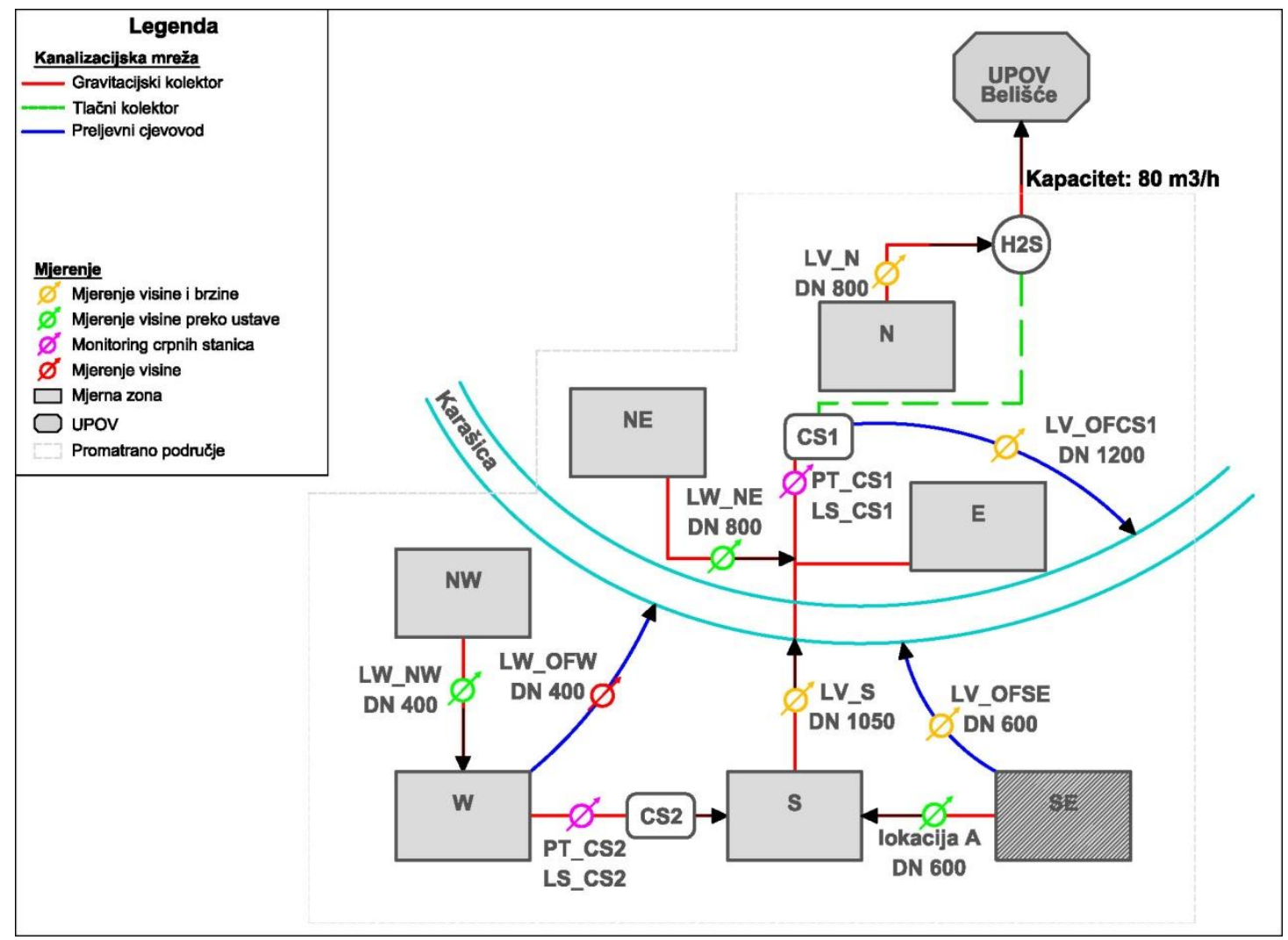

Slika 5 - Shematski prikaz karakterističnih zona i mjernih lokacija

\subsection{Izrada i postavljanje preljeva}

Preljev je potrebno izraditi pravilno i s dimenzijama prilagođenim očekivanom protoku, kako ne bi došlo do poddimenzioniranja preljeva. $U$ tom bi slučaju veći dio protoka sušnog razdoblja prelazio visinu preljeva. $U$ slučaju predimenzioniranja, preljevna visina bila bi premala što bi dovelo do smanjenja preciznosti mjerenja. Zbog toga je potrebno mjerno mjesto proučiti i prikupiti što više informacija o protocima na temelju prethodnih mjerenja protoka i brzina, analiza slivnog područja itd. Elementi potrebni za izradu preljeva definirani su na osnovi opažanja na terenu (promjena visine vode u kanalizacijskoj cijevi tijekom dana i procjena količine nanosa u cijevi), kao i probnim mjerenjima brzine strujanja u cijevi pomoću ručnog mjerača brzine. Nakon toga se pristupilo procesu projektiranja i izrade samog preljeva koji je prikazan na slici 6.
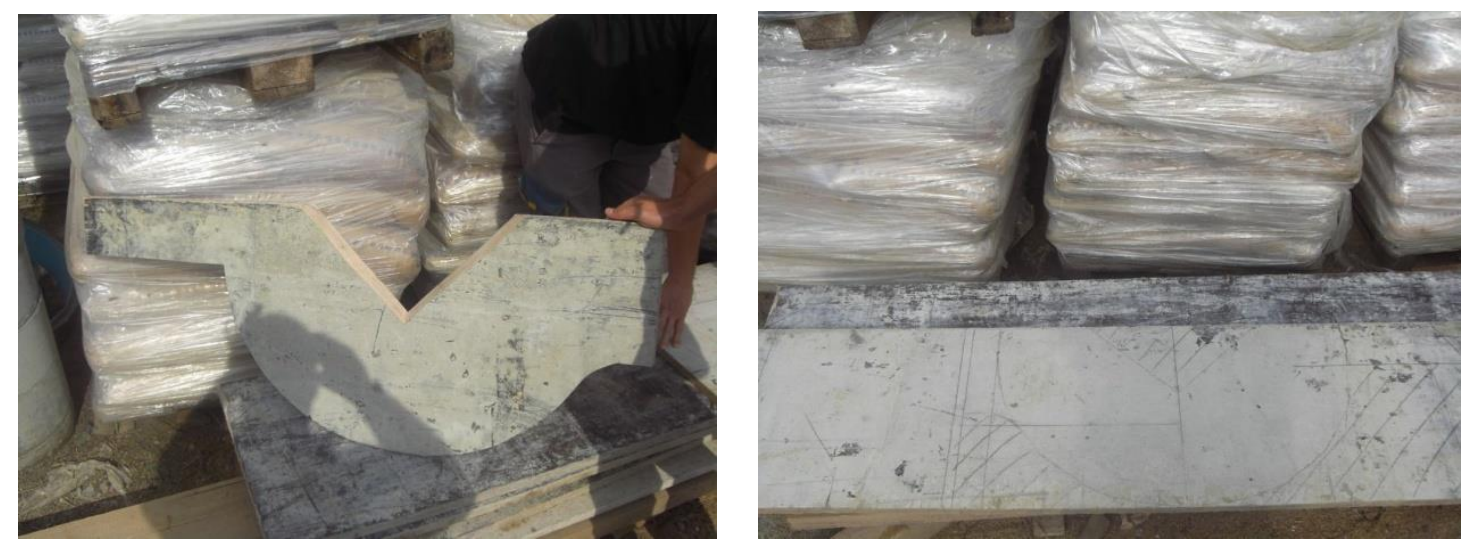

Slika 6 - Izrada trokutnog Thomsonovog preljeva 
Nakon izrade preljeva slijedi završna obrada na samoj lokaciji kako bi preljev mogao biti što bolje smješten na svoje mjesto - učvršćivanje u zidove okna, brtvljenje dodirnih mjesta radi što bolje vodonepropusnosti ispod $\mathrm{i}$ oko preljeva (slika 7).
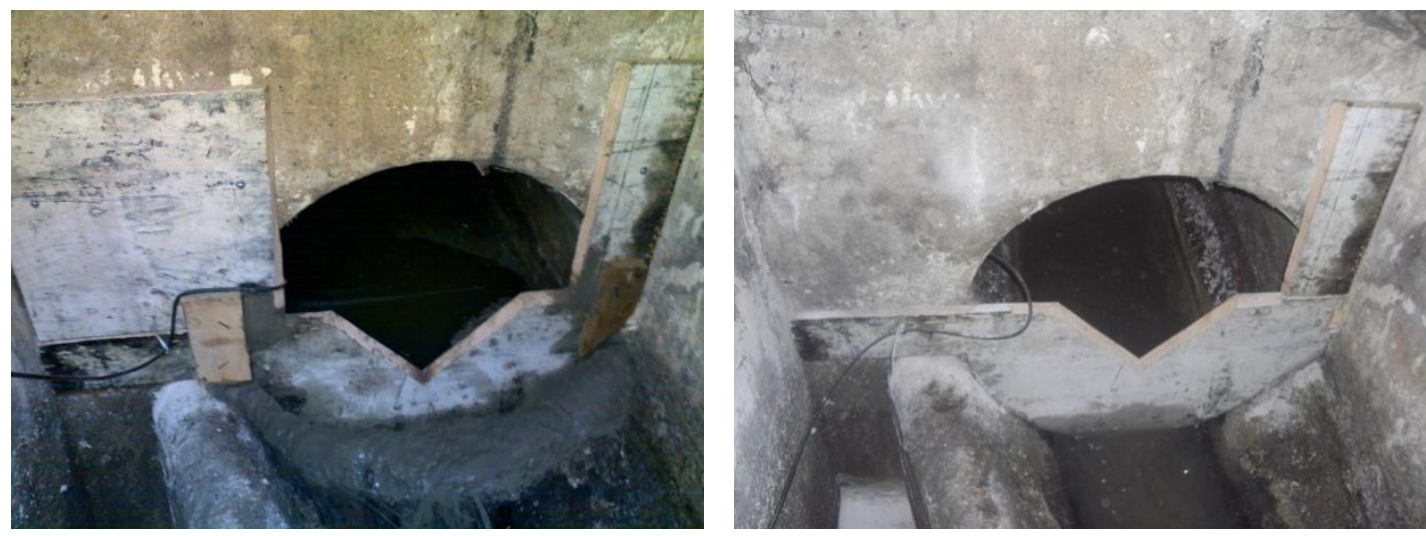

Slika 7 - Postavljanje, učvršćivanje i brtvljenje preljeva

\subsection{Programiranje i postavljanje mjerne opreme}

Uređaj za mjerenje nivoa vode naziva se pijezometrijska sonda i radi na principu registriranja pomicanja vanjske lamele zbog promjene visine vode iznad uređaja. Mjerna oprema se sastoji još i od dugačkog zaštitnog kabla te zapisivača podataka. Program koji se koristio za programiranje uređaja, prikupljanje podataka i njihovu analizu zove se WinFluid. Sam uređaj se programira prije postavljanja te se kod postavljanja definiraju dimenzije preljeva i izbalansira se početna razina vode. Samo postavljanje vrši se prije postavljanja preljeva na način da se sonda učvrsti uzvodno od preljeva na stijenku cijevi, na visini od oko $1 \mathrm{~cm}$ ispod donje točke trokutnog otvora preljeva i udaljenosti oko $60 \mathrm{~cm}$ uzvodno od preljeva.
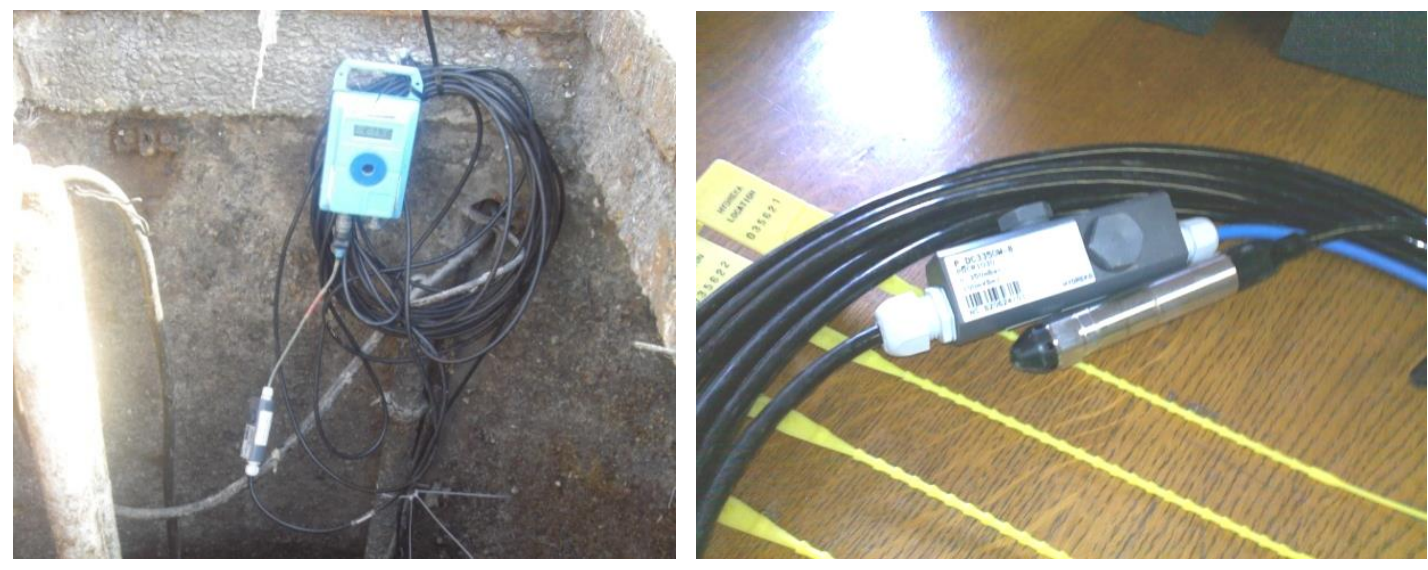

Slika 8 - Pijezometrijska sonda i zapisivač podataka

Nakon što je oprema postavljena, radi se posljednja provjera točnosti mjerenja na način da se ručnim mjerenjem provjerava strujanje mlaza preko preljeva, te se izmjereni podatci uspoređuju s očitanim podatcima zapisivača. Svakako treba napomenuti da se svi početni podatci mogu naknadno mijenjati, jer sonda registrira samo promjenu vodnog stupca iznad nje, a početnu visinu, dimenziju cijevi te geometrijske karakteristike preljeva unosimo ručno. 


\subsection{Prikupljanje podataka}

Mjerenja se vrše kontinuirano, a očitavanja i obrade periodično i završno. Zapisivač podataka ima određeni kapacitet memorije i ako mu se odredi vremenski korak zapisivanja od 1s, ta baza podataka se može vrlo brzo popuniti. Zbog toga, ali i zbog kontrole mjernog mjesta, vrši se periodično prikupljanje podataka. Podatci se prikupljaju spajanjem računala na zapisivač i snimanjem podataka s njega. Vrijeme prikupljanja podataka, podatci o lokaciji te zadnje izmjereni podatci prije snimanja, zapisuju se na evidencijske listove koji postoje za svaki mjerni uređaj. Po završetku faze mjerenja vrši se završno prikupljanje gdje se ponovno skidaju svi podatci, ali se ono vrši u zatvorenim prostorijama kako bi se detaljno moglo obaviti završno pregledavanje svih izmjerenih podataka te zapisivač podataka vratiti u početno stanje.

\section{Analiza i obrada podataka}

\subsection{Analiza rezultata mjerenja}

Mjerenje protoka Thomsonovim preljevom u ovom slučaju obuhvaća mjerenje protoka u tzv. sušnom razdoblju, kada su u mješovitom kanalizacijskom sustavu prisutne samo kućanske otpadne vode, odnosno kada je visina preljevnog mlaza bila do gornjeg ruba trokutnog preljeva. Zbog toga je bitno iz dobivenih podataka izdvojiti dane kada je režim u sustavu javne odvodnje bio takav da su preljevne visine prelazile visinu trokutastog dijela preljeva ili dane kada su izmjereni rezultati nerealni. To se može odraditi direktno u programu WinFluid ili u programu MS Excel.

Na slici 9 prikazani su neobrađeni podatci mjerenja preljevnih visina na lokaciji $A$, u razdoblju od 10 . kolovoza do 3. rujna 2010.godine. Ovi podatci su prvi pokazatelj nelogičnih i nezadovoljavajućih rezultata.

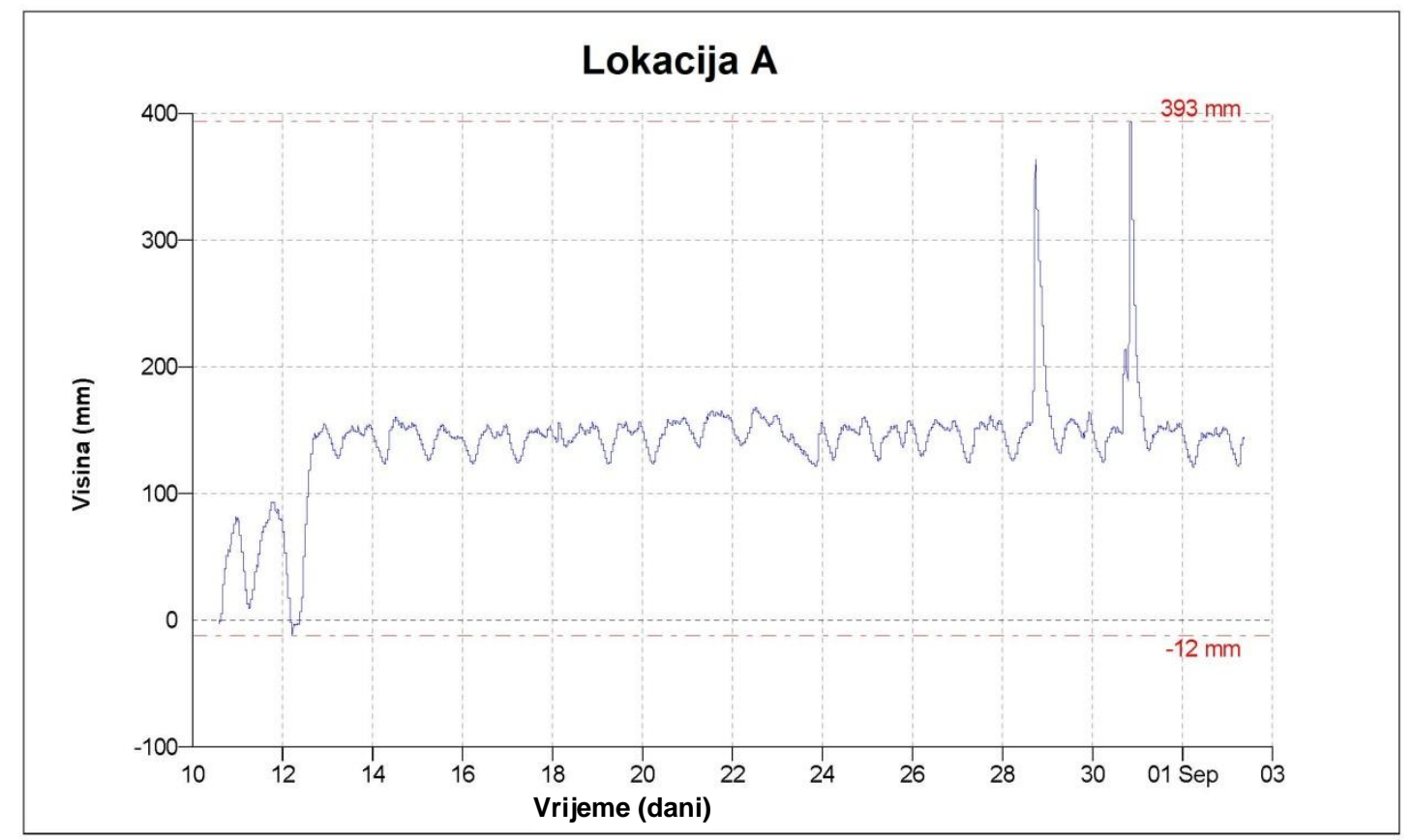

Slika 9 - Neobrađeni rezultati mjerenih preljevnih visina

U ovom slučaju prva tri dana mjerenja pokazuju čak negativne visine. To je nastalo zbog propuštanja vodonepropusnog brtvenog sloja koji je popravljen, te su od 14. kolovoza rezultati vidljivo bolji i kontinuirani. Dva vrha dijagrama pokazuju dvije kišne epizode, 29. i 31. kolovoza, koje će se isključiti iz daljnje analize jer analiza pokriva samo suha razdoblja, odnosno razdoblja u kojima je visina preljevnog mlaza bila u razini gornjeg ruba trokutnog Thomsonovog preljeva $(200 \mathrm{~mm})$. 
Obradom ovih podataka dolazimo do preljevnih visina koje prezentiraju bazu podataka prihvatljivu za daljnju obradu (slika 10).

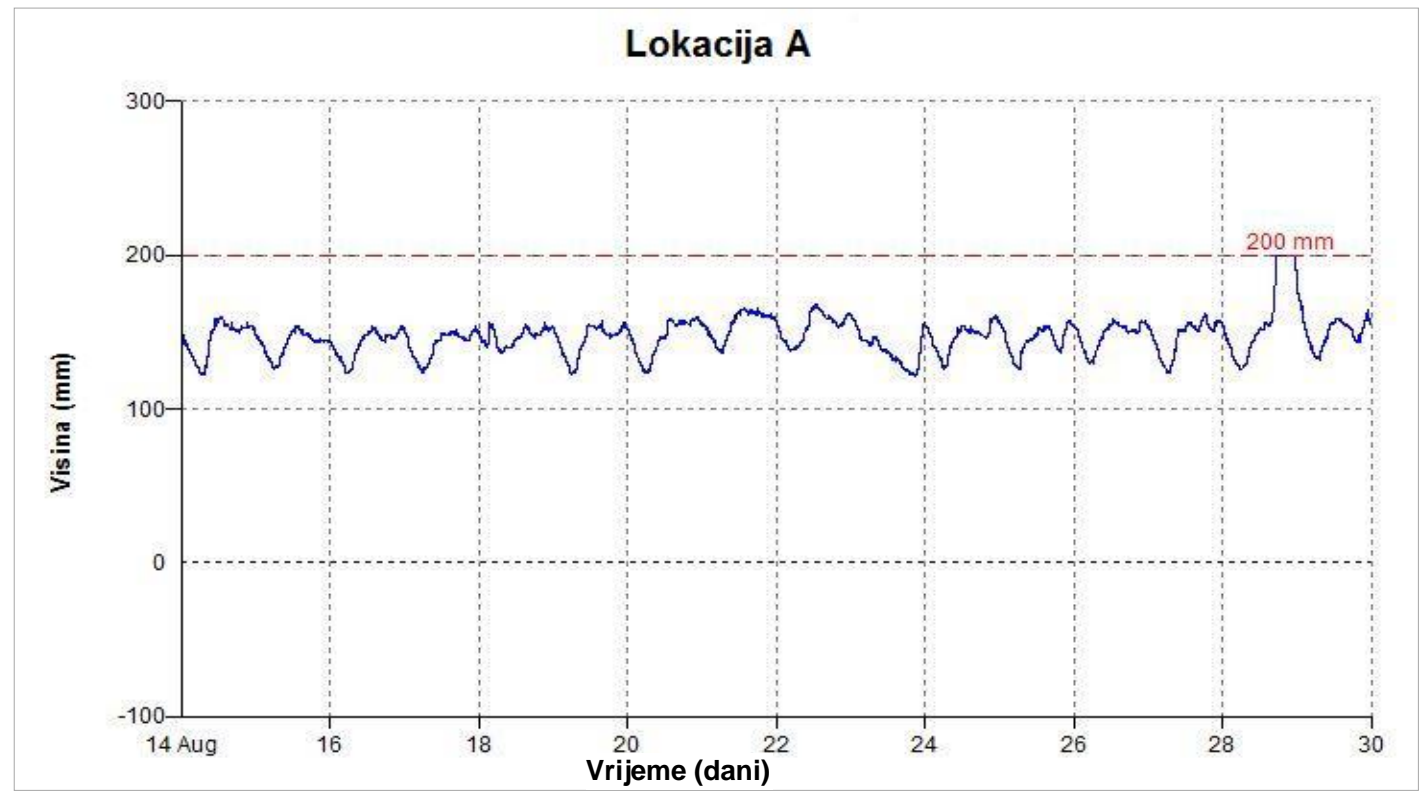

Slika 10 - Obrađeni rezultati mjerenja preljevnih visina

Detaljniji pregled oscilacija visina preljevnog mlaza u svakom satu po danima može se napraviti unutar programa MS Excel te na taj način provjeriti i satnu kontinuiranost mjerenja i dodatno utvrditi postojanje ekstremnih vrijednosti (slika 11). Na slici su vidljiva dva odstupanja u ponašanju mjerenih visina prelijevanja. U ta dva dana padale su intenzivnije oborine i visina prelijevanja prešla je gornij rub Thomsonovog preljeva.

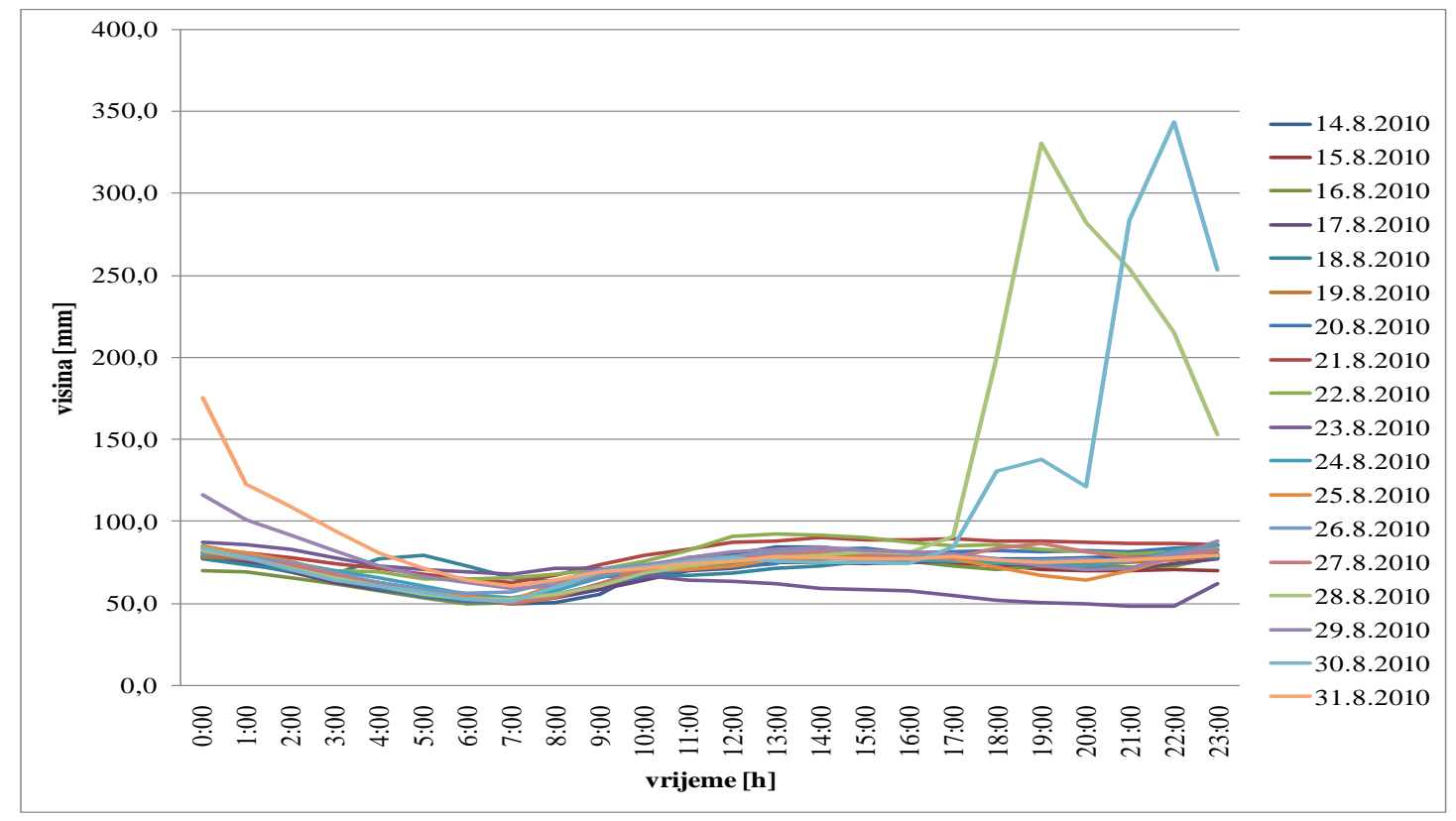

Slika 11 - Satne oscilacije preljevnih visina 


\subsection{Izračun dotoka sušnog razdoblja}

Za proračun protoka pomoću modela WinFluid nužno je definirati geometrijske karakteristike preljeva na način kako je prikazano na slici 12. Pritom mora biti zadovoljeno sljedeće:

$$
\begin{array}{ll}
-20^{\circ}<\theta<100^{\circ} & -H \max / \mathrm{P}<0,35 \\
-\mathrm{P}>0,09 \mathrm{~m} & -0,06 \mathrm{~m}<\mathrm{Hp} \\
-0,10<\mathrm{P} / \mathrm{B}<1,5 & -H \min <\mathrm{Hp}<\mathrm{Hmax}
\end{array}
$$

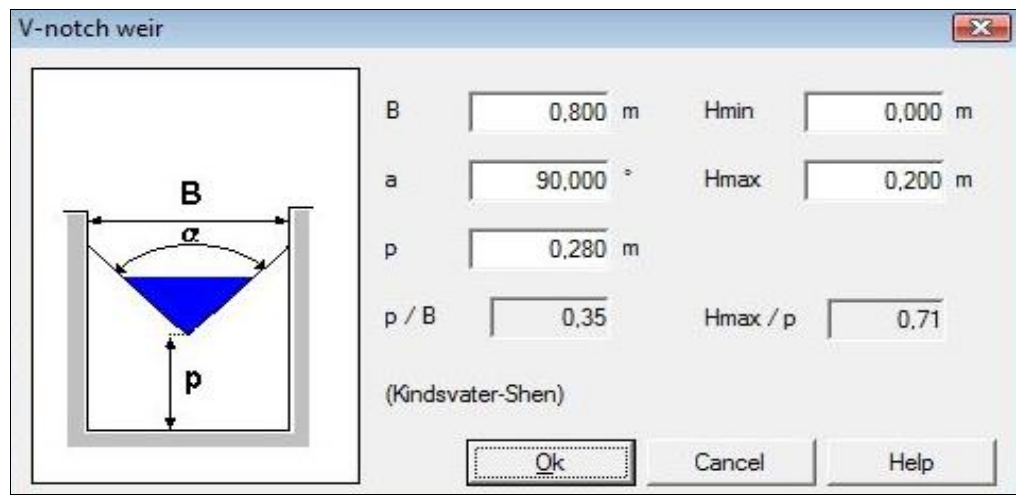

Slika 12 - Geometrijske karakteristike preljeva modela

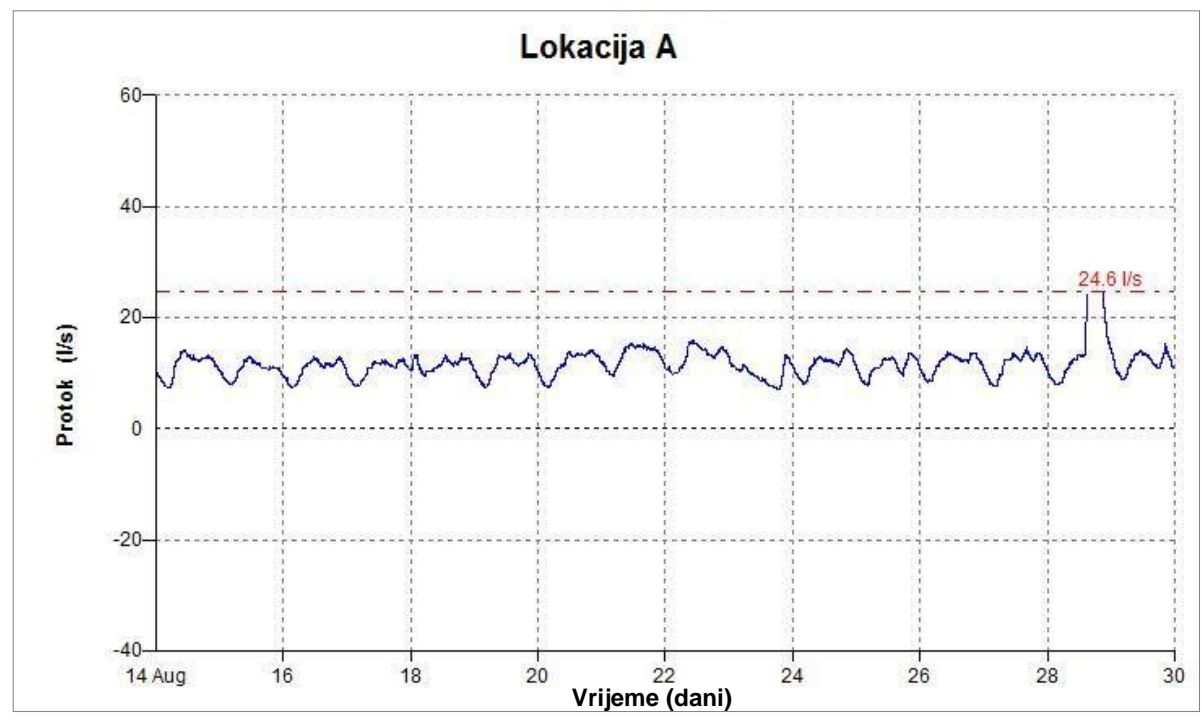

Slika 13 - Hidrogram za odabrane dane mjerenja i preljevne visine ispod $200 \mathrm{~mm}$

Na slici 13 prikazan je konačni dnevni hidrogram za kanalizacijsku cijev u razdoblju od 14. kolovoza do 30. kolovoza, dobiven na osnovi mjerenja preljevnih visina s ograničenjem na protoke, pri visinama prelijevanja ispod $200 \mathrm{~mm}$. Na slici je označen protok od 24,6 I/s koji predstavlja maksimalno izmjeren protok na preljevnoj visini od $200 \mathrm{~mm}$.

Rezultati mjerenja koristili su se za izradu baze podataka u uvjetima sušnog dotoka. Zbog tog razloga, svi kišni dani maknuti su iz rezultata te se izradila satna krivulja radi očitavanja traženih dotoka sušnog razdoblja (slika 14). 


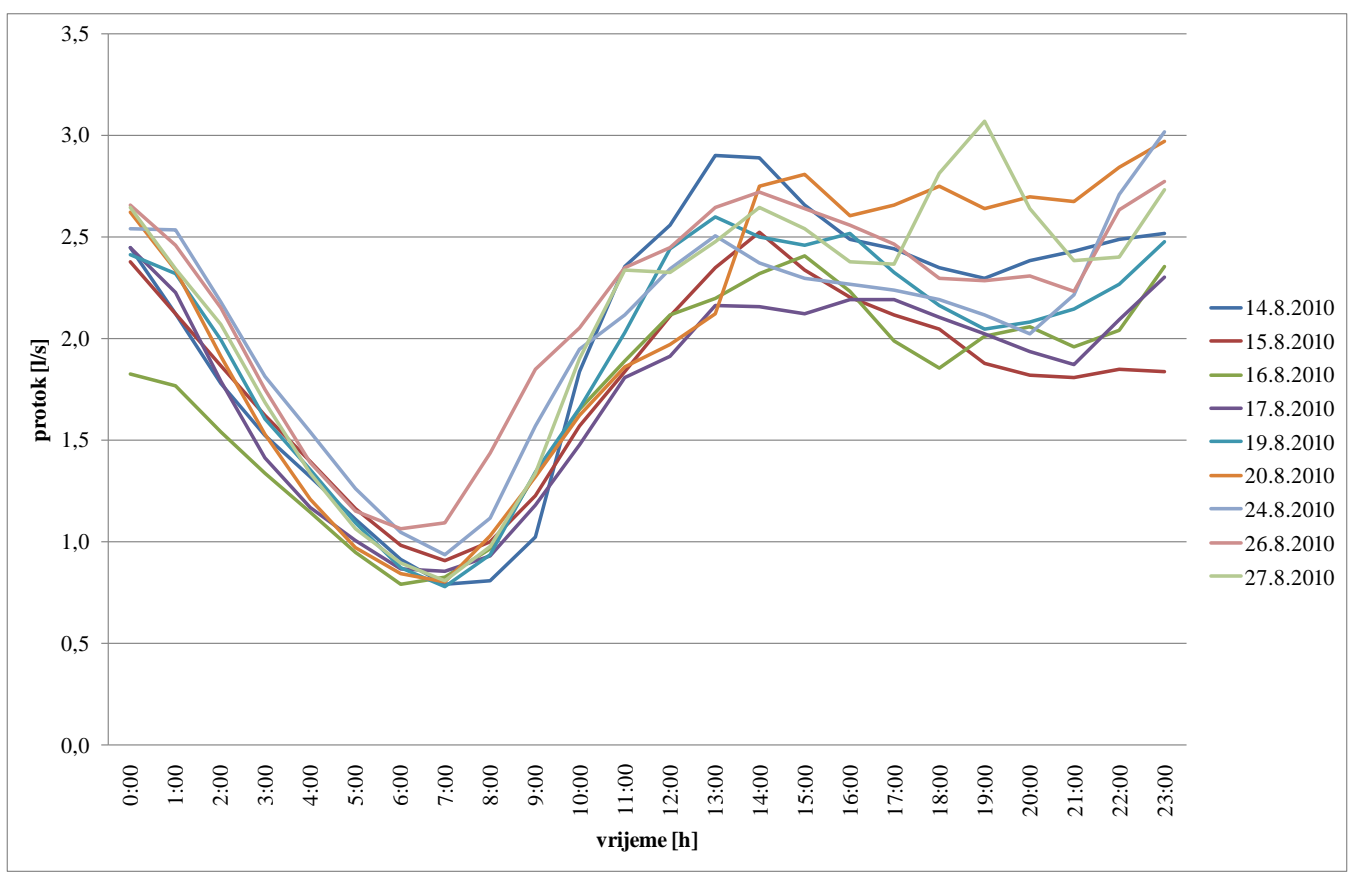

\section{Slika 14 - Dotok sušnog razdoblja}

Temeljem proračuna protoka definiraju se ostali parametri koji pobliže definiraju promatrano slivno područje u uvjetima sušnog dotoka, odnosno uzimajući u obzir samo kućanske otpadne vode. Također su korišteni i podatci o potrošnji vode. Analiza ovih podataka daje sljedeće rezultate:

- prosječni udio tuđih voda (procjeđivanje kroz spojeve): 0,56 l/s, odnosno 29\% (dobiveno promatranjem najučestalijih malih protoka u noćnim satima, kada je mjerena potrošnja pitke vode bila približno 0 l/s);

- prosječni protok kućanskih otpadnih voda: 1,39 I/s;

- prosječna potrošnja pitke vode: $1,98 \mathrm{l} / \mathrm{s}$;

- stopa povrata: $70 \%$ (razlika između utrošene pitke vode i vode ispuštene u sustav javne odvodnje);

- indeks tuđih voda: $5,8 \mathrm{I} / \mathrm{dan} / \mathrm{km}$ (dnevna količina procijeđene vode po kilometru mreže za promatranu zonu).

Promatrano područje spada u područje mješovite namjene (kućanstva i industrija). Dobiveni rezultati nam pokazuju udio tuđih voda od $29 \%$ koji bi lokalnim zahvatima mogao biti smanjen. Podatci o prosječnoj potrošnji pitke vode dobiveni su mjerenjem protoka na glavnim dovodnim cjevovodima istog područja, te podatcima 0 potrošnji po kućanstvima za ulice, naselja i industriju promatranog područja.

\subsection{Kalibracija hidrauličkog modela}

Cilj provedbe mjerenja protoka u kanalizacijskom sustavu je prikupljanje podataka koji će poslužiti za kalibraciju modela sustava javne odvodnje područja grada Valpova, model (Epa SWMM). Dio promatranog područja prikazan je na slici 1. Kalibracija se u ovom slučaju provodi mjerenjem protoka, a moguće ju je provoditi i mjernjem brzina.

Slika 15 prikazuje sustav javne odvodnje s definiranim slivnim područjima, crpnim stanicama, cjevovodima i revizijskim oknima. Unutar modela definirana je i dionica na kojoj je izvršeno mjerenje. Za potrebe kalibracije modela, na temelju dobivenih mjerenih i obrađenih podaka računaju se prosječni satni protoci sušnog razdoblja, odnosno definira se 24-satni hidrogram prikazan na slici 16. 


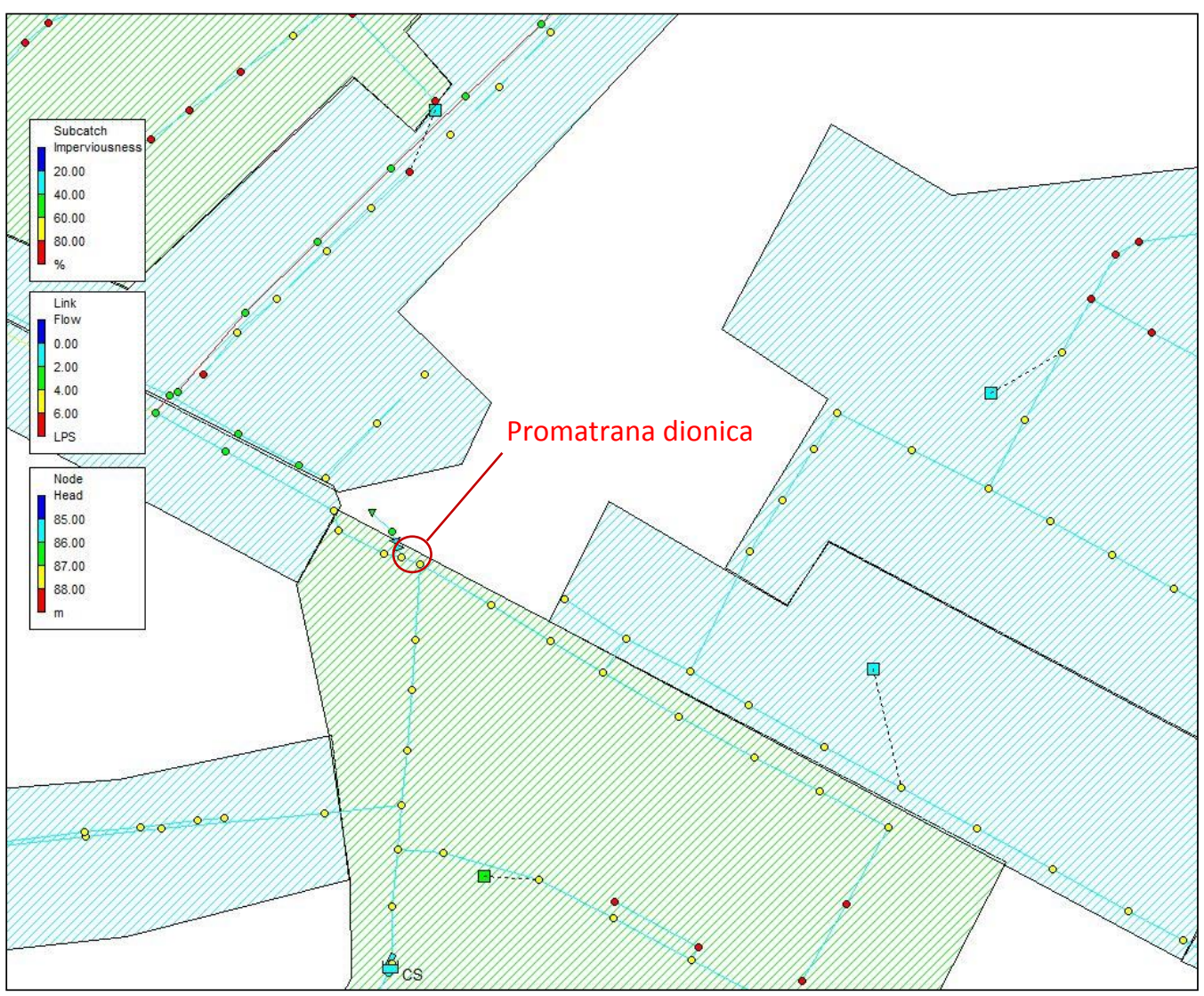

Slika 15 - Hidraulički model promatranog područja

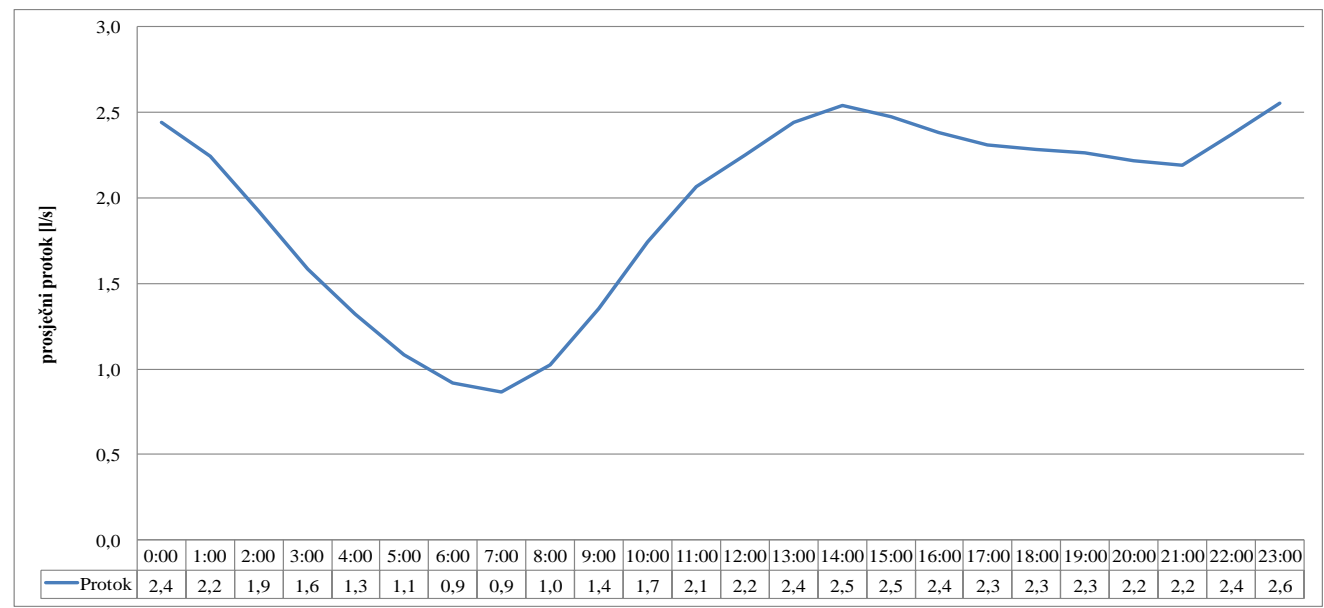

Slika 16 - Dnevni hidrogram

$\mathrm{Na}$ slici 17 prikazan je hidrogram dobiven mjerenjem protoka pomoću trokutnog Thomsonovog preljeva (kalibracijski hidrogram) i hidrogram izračunat hidrauličkim modelom. Usporedba ova dva hidrograma samo je djelomično zadovoljavajuća jer su odstupanja pri malim protocima dosta velika (tijekom noći), a pri većim protocima (tijekom dana) su dosta mala. Obrazloženje ove pojave je u brzini reakcije samog modela pri opadanju protoka. Ako želimo kvalitetni hidraulički model pomoću kojega možemo modelirati sve potrebne podatke, i to sa zadovoljavajućom točnošću kako bismo mogli poboljšati postojeći sustav javne odvodnje, tada je potrebno provesti određene provjere i poboljšanja kao i dodatne provjere. 


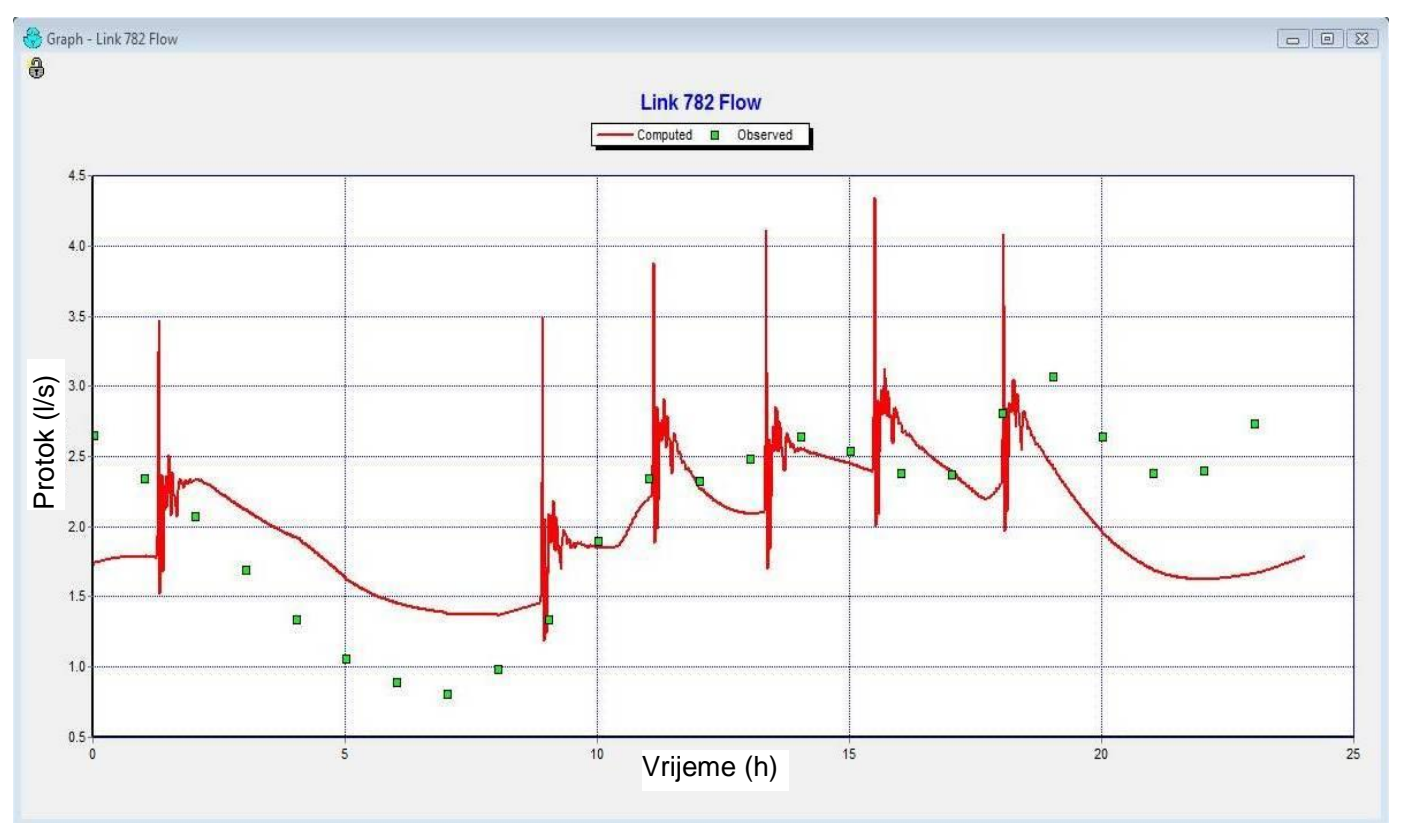

Slika 17 - Kalibracija hidrauličkog modela

\section{Zaključak}

Ovim radom prikazana je jedna od mogućnosti primjene trokutnog Thomsonovog preljeva u mjerenju protoka sustava javne odvodnje. Proces mjerenja zahtijeva detaljnu analizu, izradu i postavljanje preljeva, programiranje i postavljanje mjernih uređaja te kvalitetno prikupljanje i obradu podataka, kako bi izlazni rezultat bio kvalitetna baza podataka koju možemo primijeniti na razne načine. $U$ ovom radu prikazan je primjer primjene mjerenih i obrađenih podataka za kalibraciju protoka hidrauličkog modela tijekom sušnog (bezoborinskog) razdoblja i pokazao da je hidraulički model potrebno još provjeriti i doraditi. Hidraulički modeli sustava javne odvodnje mogu nam dati veliki broj informacija potrebnih za projektiranje, održavanje, provođenje mjera poboljšanja sustava i racionalizacije operativnih troškova, te stoga moraju biti pouzdani i zadovoljavajuće točnosti. $U$ analiziranom primjeru kalibracije protoka na kanalizacijskoj odvodnji, razlika između modela i mjerenja u satima pada protoka i manjih protoka tijekom noćnih sati je reda veličine $40 \%$, dok je pri većim protocima razlika manja od $10 \%$.

Dobiveni podatci mogu se dalje primjenjivati u kalibraciji rada crpnih stanica, analizi stanja sustava tijekom kišnog razdoblja ili u izradi hidrauličkog modela nekog drugog sličnog područja.

\section{Literatura}

[1] Jović, V. Zagreb 2006.: Osnove hidromehanike

[2] Vuković, Ž. Zagreb 1994.: Osnove hidrotehnike 1/1

[3] Centre d'Etudes Techniques Maritimes Et Fluviales (CETMEF), Compienge Cedex, Francuska, 2005.: Notice sur les déversoirs - Synthèse des lois d'écoulement au droit desseuils et déversoirs [Hrv.: Upute za preljeve - Skup svih zakonitosti protoka preko pregrada i preljeva]

[4] Bengston, H.: Mjerenje otvorenim kanalima 4: V - preljev; http://www.brighthub.com/engineering/civil/articles/65701.aspx

[5] United States Department of the Interior Bureau of Reclamation, Washington DC, SAD, 2001.: Water Measurement manual

[6] Dundović, I. Osijek 2011.: Mjerenje protoka pomoću Thomsonovog preljeva, diplomski rad 